Secretary, Mr. J. W. Y. Higgs (Department of Agriculture, University of Oxford). Mr. Alexander Hay, Mr. M. W. Beresford and Mr. G. E. Fussell were elected to vacancies on the Executive Committee. Mr. George Ordish was re-appointed executive chairman at a later meeting of the Executive Committee. The Society's journal, The Agricultural History Review, has now become a recognized medium for the publication of original papers on branches of the history of agriculture, and the Society is in a sound financial position. A further substantial addition to the number of members would make it possible to add to the progress already made since the Society's foundation.

\section{Meeting of Nobel Prize-Winners in Lindau}

THe annual conference of Nobel Prize-Winners at Lindau, Lake Constance, will be held during June 30-July 4 and will be devoted to various aspects of chemistry. The following addresses will be delivered : Prof. A. W. K. Tiselius (Upsala), "Die Nobelstiftung, ihre Tradition und ihr Wirken"; Prof. Adolf Butenandt (Münich), "Das Leben als Gegenstand chemischer Forschung" ; Prof. Hans von Euler-Chelpin (Stockholm), "Chemische Struktur und biochemische Wirkungen"; Prof. Georg von Hevesy (Stockholm), "Radioaktive' Markierung von Zellen"; Prof. Paul Karrer (Zurich), "Neuere Forschungsergebnisse über das Pfeilgift Curare"; Prof. F. Joliot-Curie (Paris), "Das neue Forschungszentrum für Grundlagen der Kernphysik in Orsay und die Ausbildung der Forscher"; Prof. Ludwig Ruzicka (Zurich), 'Zur Biogenese organischer Naturverbindungen"; Prof. R. L. M. Synge (Rowett Research Institute, Bucksburn), "Natural Peptides and their Biological Significance" ; Sir Alexander Todd (Cambridge), "Some Observations on Nucleotide Coenzymes" ; Prof. A. I. Virtanen (Helsinki), "Antimikrobielle Substanzen in Kulturpflanzen und deren Bedeutung für die Widerstandfahigkeit der Pflanzen und für die Ernährung der Haustiere und des Menschen"; Prof. R. Kuhn (Heidelberg), "Ưber die Amadori-Verbindungen". A comprehensive programme of excursions has also been arranged. Further details can be obtained from the Ständiger Arbeitsausschuss für die Tagungen der Nobelpreisträger, Lindau im Bodensee, Postfach 11.

\section{Announcements}

DR. D. H. Brack, director-general of electronics research and development, Ministry of Supply, has been appointed director of the Armament Research and Development Establishment at Fort Halstead, in succession to Mr. Ewen M'Ewen, who has left the public service to take a post in industry.

Mr. Patrick Duncan MoTaggart-Cowan, assist: ant director of the Meteorological Branch of the Canadian Department of Transport, has been appointed associate director with Andrew Thomson, Dominion Meteorologist and director of the Branch. Mr. McTaggart-Cowan, who graduated from the University of British Columbia with first-class honours in mathematics and physics in 1933 and then proceeded to the University of Oxford with a Rhodes scholarship, joined the Canadian Meteorological Service in 1936.

The Academy of Sciences, Paris, recently created a French National Committee of Biochemistry to represent France in connexion with the International
Union of Biochemistry. The following officers have been appointed: Honorary President, G. Bertrand; President, R. Fabre; Vice-Presidents, M. Lemoigne, Prof. J. Roche, R. Bernier; Secretary General, Prof. J. E. Courtois (4 Avenue de l'Observatoire, Paris 6e); Assistant Secretary, Prof. Y. Raoul ; Treasurer, Dr. R. Midy.

THE following have been elected to Beit Fellow. ships for Scientific Research, of the value of $£ 600$ per annum, at the Imperial College of Science and Tech. nology, London : Mr. F. J. J. Clarke, for research on peripheral vision under Prof. W. D. Wright (technical optics); Mr. D. G. Watts, for research in the field of control technology under Prof. A. Tustin (heavy electrical engineering).

THE first members' day of the National Vegetable Research Station Association will be held on June 12. Further information can be obtained from the Secretary, National Vegetable Research Station Association, Wellesbourne, Warwick.

Av international Congress of Radiation Research will be held at the University of Vermont, Burlington, Vermont, during August 10-16, sponsored jointly by the National Academy of Sciences-National Research Council and the Rediation Research Society in cooperation with the European Committee on Radiobiology. In addition to symposia on "The Role of Oxygen and Peroxides in Radiation Chemistry: Analysis and Correlation of Various Radiobiological Actions on the Same Cell Species (Yeast)", "Free Radicals produced by Irradiation", "Late Effects of Irradiation in Mammals" and "Induced Changes in Deoxyribonucleic Acid and in Chromosome Structure", plenary sessions will be held on the progress and status of radiation research. Further information can be obtained from Dr. Harvey M. Patt, Secretary General, International Congress of Radiation Research, Argonne National Laboratory, Post Office Box 299, Lemont, Illinois.

THF Fifteenth International Dairy Congress is being held in London during June 29-July 3,1959, under the auspices of the International Dairy Federation. In order to assist the authors of contributions in preparing their manuscripts and to ensure a degree of uniformity and high quality among the papers and communications, the Congress authorities have issued a booklet entitled "Instructions to Authors". The booklet is available in three editions-English, French and German-the three official languages of the Congress. It is obtainable from the International Dairy Federation National Committee or the Congress Liaison Officer in each country, or from A. W. Marsden, Organizing Secretary, XV International Dairy Congress, 86 Brook Street, London, W.1. Titles of contributions must reach the organizing secretary not later than June 1, 1958, and the full papers or communications themselves not later than September 1, 1958.

IN an article entitled "Machines as Models in Biological Experiments" in Nature of April 26, p. 1187, it was implied that "Collected Papers, Vol. 6" of the Laboratory Animals Bureau consisted of a paper by Dr. W. Grey Walter. This is incorrect; the booklet mentioned in the footnote consists of papers and abstracts from a symposium on "Humane Technique in the Laboratory", arranged by the Universities Federation for Animal Welfare, and held in London on May 8, 1957. 